\title{
Skutki ustawy S.447 przyjętej przez Kongres Stanów Zjednoczonych w dniu 12 grudnia 2017 r. pt. Justice for Uncompensated Survivors Today (Sprawiedliwość dla pozostałych przy życiu ocalonych w dzisiejszych czasach) ${ }^{1}$
}

Consequences of the United States Congress's Act of $12^{\text {th }}$ December 2017, titled the Justice for Uncompensated Survivors Today - S.447 (WAPM-28/18): Despite the fact that the Act S.447 is an act of American domestic law, it is important for United States' foreign policy towards covered countries. Its specific repercussion are difficult to predict. The Act contains a negative assessment of the Polish legislation and its execution within restitution of properties nationalised during the period of the Holocaust and within the provisions regarding nationalisation issued by communist authorities after 1944, in the context of targets and assumptions of the Holocaust Era Assets Conference 2009. The currently binding Polish legislation, as well as administrative and judicial practice do not meet criteria set out in the Act S.447. Despite that critical assessment, a satisfaction from Poland's property which is situated on USA's territory, is impossible due to judicial and execution immunity applying to that property.

Keywords: property, nationalisation, reprivatisation, USA, World War II, Jews Słowa kluczowe: majątek, nacjonalizacja, reprywatyzacja, USA, II wojna światowa, Żydzi

\section{Przedmiot opinii}

Przedmiotem opinii jest udzielenie odpowiedzi na trzy pytania:

- czy w opinii Biura Analiz Sejmowych obowiązujące obecnie w Polsce regulacje prawne i ich wykonywanie w zakresie zwrotu mienia znacjonalizowanego w okresie Holokaustu oraz w ramach przepisów nacjonalizacyjnych wydanych przez władze komunistyczne po 1944 r. spełniają kryteria wskazane

1 Opinia sporządzona 14 marca 2018 r. na zlecenie Klubu Kukiz'15; BAS-WAPM 28/18. 
w celach i założeniach Holocaust Era Assets Conference z 2009 r., o których mowa w ustawie S.447 (jakie kryteria, w jaki sposób są spełnione, jeśli nie, dlaczego nie; jakie są przewidywania BAS w sprawie wniosków raportu sekretarza stanu w kontekście Polski),

- czy przyjęcie w obecnym brzmieniu przedstawionego projektu ustawy o zrekompensowaniu niektórych krzywd wyrządzonych osobom fizycznym wskutek przejęcia nieruchomości lub zabytków ruchomych przez władze komunistyczne po 1944 r. (dalej: projekt ustawy o rekompensacie) będzie miało wpływ na ocenę zawartą w odpowiedzi na pierwsze pytanie i jeśli tak, jaki to będzie wpływ?,

- jakie mogą być przewidywane konsekwencje prawne, w szczególności dla Polski, negatywnej oceny polskich regulacji prawnych i ich wykonywania w zakresie zwrotu mienia znacjonalizowanego w okresie Holokaustu oraz w ramach przepisów nacjonalizacyjnych wydanych przez władze komunistyczne po 1944 r. w kontekście celów i założeń Holocaust Era Assets Conference.

Opinia nie dotyczy zgodności obowiązującego lub projektowanego prawa polskiego z Konstytucją RP, umowami międzynarodowymi wiążącymi Polskę ani też oceny słuszności czy zasadności rozwiązań zawartych w projekcie ustawy o rekompensacie.

\section{Uwagi ogólne}

Udzielenie odpowiedzi na przedstawione pytania wymaga scharakteryzowania treści amerykańskiej ustawy S.447 pt. O wymogu sprawozdawczym w sprawie ustaw niektórych państw obcych $w$ odniesieniu do aktywów uzyskanych $z$ Holokaustu i problemów z nimi związanych, określonej w skrócie jako Sprawiedliwość dla pozostałych przy życiu ocalonych $w$ dzisiejszych czasach (dalej: ustawa S.447 lub ustawa).

Zasadniczym celem i przedmiotem ustawy S.447 jest ustanowienie obowiązku przedłożenia przez sekretarza stanu w terminie nie dłuższym niż 18 miesięcy od daty uchwalenia ustawy sprawozdania do właściwych komisji Kongresu Stanów Zjednoczonych (są to cztery komisje: spraw zagranicznych oraz budżetowe (appropriations) odpowiednio Izby Reprezentantów i Senatu), w którym dokona on oceny i opisu charakteru i zakresu ustawodawstwa krajowego i polityki jego wykonywania w odniesieniu do państw nim objętych (covered countries) w zakresie identyfikacji i zwrotu lub odzyskania bezprawnie zajętych lub przekazanych (wrongfully seized or transferred) aktywów z Holokaustu, zgodnie z celami (goals and objectives) Konferencji nt. Aktywów z Holokaustu z 2009 r. ${ }^{2}$

2 Zob. stronę Konferencji: http://www.holocausteraassets.eu/. Polskiej delegacji przewodniczył W. Bartoszewski, wówczas sekretarz stanu i pełnomocnik Prezesa Rady Ministrów ds. dialogu międzynarodowego. 
i ocenianych z perspektywy poszanowania tych celów (subsekcja b). Obowiązek sprawozdawczy nie wyczerpuje się jednak w tym sprawozdaniu, lecz ma być kontynuowany (subsekcja c).

Ustawa zalicza do covered countries państwa uczestniczące w Konferencji z 2009 r., które są określone przez sekretarza stanu lub osobę wyznaczoną przez niego w konsultacji z ekspertami organizacji pozarządowych jako kraje szczególnie zainteresowane problemami wymienionymi w sekcji b ustawy. $Z$ kolei termin „bezprawnie zajęte lub przekazane” pojmuje się jako obejmujący konfiskaty, wywłaszczenia, nacjonalizację, przymusową sprzedaż aktywów, sprzedaż lub transfer w warunkach przymusowych (duress) podczas Holokaustu lub w okresie rządów komunistycznych w covered countries (subsekcja a).

Ustawa S.447 ustala kryteria, według których mają być oceniane ustawodawstwa covered countries. W subsekcji b wymienia się (nie jest jasne, czy w sposób wyczerpujący, gdyż używa się terminu including, co raczej wskazuje na wyliczenie przykładowe) następujące elementy oceny:

1) zwrot prawowitemu właścicielowi wszelkiej własności, w tym własności religijnej lub wspólnotowej (communal), która została bezprawnie zajęta lub przekazana,

2) jeśli zwrot, o którym mowa w punkcie 1 nie jest już możliwy, zapewnienie porównywalnej własności lub zapłata słusznej kompensaty prawowitemu właścicielowi zgodnie z zasadami sprawiedliwości i w przyspieszonym trybie administracyjnym (expeditious claims-driven administrative process), który jest sprawiedliwy, przejrzysty i uczciwy (just, transparent, and fair),

3) w przypadku własności bezdziedzicznej, zapewnienie własności lub kompensaty w celu udzielenia pomocy potrzebującym ocalonym z Holokaustu, wspierania edukacji o Holokauście lub w innych celach,

4) zakres, w jakim takie ustawodawstwo i polityki są wykonywane i egzekwowane $w$ praktyce, $w$ tym $w$ ramach wszelkich mających zastosowanie procedur administracyjnych i sądowych,

5) w możliwym zakresie mechanizm i przegląd postępu w kierunku rozstrzygania o roszczeniach ocalonych z Holokaustu będących obywatelami Stanów Zjednoczonych oraz członków rodzin ofiar Holokaustu będących obywatelami Stanów Zjednoczonych.

W komentarzu do tej regulacji należy podnieść, co następuje:

- jest to ustawa Stanów Zjednoczonych, która zgodnie z zasadami sprawowania jurysdykcji legislacyjnej w rozumieniu prawa międzynarodowego (zasada terytorializmu) $)^{3}$ obowiązuje i podlega wykonaniu na terytorium Stanów Zjednoczonych; jest zarazem wiążąca wyłącznie wewnętrznie, a jej bezpośrednim adresatem jest sekretarz stanu USA;

3 C. Ryngaert, Jurisdiction in International Law, Oxford University Press, Oxford 2008, s. 42 i $n$. 
- ustawa nie nakłada sama w sobie żadnych środków restrykcyjnych na covered countries (jako taka nie zmierza do wywierania tzw. skutków ekstraterytorialnych), lecz jedynie zobowiązuje sekretarza stanu do oceny obcego ustawodawstwa i obcej praktyki państwowej; taka ocena może jednak posłużyć do działań politycznych i, w pewnym stopniu, prawnych w relacjach $\mathrm{z}$ covered countries, wszakże decyzje w tej materii nie zapadną automatycznie po stwierdzeniu naruszania kryteriów, o których mowa w subsekcji b,

- przedmiotem ustawy jest dokonanie przeglądu ustawodawstwa i praktyki (istnienie i działanie procedur administracyjnych i sądowych) covered countries oraz sformułowanie oceny ich dotyczącej w zakresie wykonania celów Konferencji nt. Aktywów z Holokaustu. W ustawie wymienia się przy tym 5 kryteriów oceny ustawodawstwa i praktyki covered countries. Generalnie kryteria zmierzają do odzyskania utraconego w wyniku Holokaustu mienia żydowskiego, najpierw w naturze, w razie niemożliwości restytucji - naprawy szkód w postaci mienia zastępczego o porównywalnej wartości albo kompensaty pieniężnej. W przypadku mienia bezdziedzicznego zapewnienie mienia lub kompensaty będącym w potrzebie ocalałym z Holokaustu, sfinansowanie edukacji o Holokauście lub innych celów. W ostatnim z kryteriów istnieje mechanizm dochodzenia roszczeń przez ocalałych z Holokaustu obywateli Stanów Zjednoczonych i członków rodzin będących obywatelami Stanów Zjednoczonych wraz z możliwością przeglądu postępu w zaspokajaniu tych roszczeń. Wyłącznie w ostatnim wypadku ustawodawca amerykański odwołał się do kryterium obywatelstwa tego państwa.

Szerokie sformułowanie kryteriów rodzi liczne wątpliwości. W pierwszym rzędzie pojawia się pytanie, czy poza ostatnim kryterium Stany Zjednoczone uregulowały w ustawie sytuację wszelkich Żydów dotkniętych Holokaustem, w tym niebędących obywatelami Stanów Zjednoczonych, czy jednak jej zastosowanie odnosi się tylko do obywateli Stanów Zjednoczonych? Przy zastosowaniu drugiego kryterium wskazuje się, że w przypadku mienia zastępczego czy też (słusznej) kompensaty kluczowe mają być zasady sprawiedliwości oraz istnienie szybkich procedur administracyjnych dochodzenia roszczeń, które spełniają wymogi sprawiedliwości, przejrzystości i uczciwości (just, transparent, and fair). Nie jest jasne, czy takie procedury mają istnieć tylko w tym przypadku, czy także w sytuacji restytucji bądź mienia bezdziedzicznego, jak należy rozumieć słuszną kompensatę (jako pełną, proporcjonalną, maksymalnie możliwą w warunkach danego państwa?), jak należy rozumieć zasady sprawiedliwości, jakie w istocie kryteria składają się na wymogi dotyczące procedury administracyjnej. Wysoce niejasne pozostaje także kryterium związane $\mathrm{z}$ mieniem bezdziedzicznym w zakresie przyznania mienia lub kompensaty ocalałym z Holokaustu osobom, pozostającym w potrzebie. Według jakich standardów miałaby nastąpić ocena pozostawania w potrzebie? 
Wątpliwości te z jednej strony otwierają możliwości szerokiej wykładni ustawy, a z drugiej utrudniają udzielenie odpowiedzi na pytania postawione we wstępie niniejszej opinii.

- Pierwsze pytanie dotyczy w istocie tego, czy obecnie obowiązujące ustawodawstwo i praktyka w zakresie zwrotu mienia żydowskiego spełnia kryteria wymienione w ustawie S.447 i, jeśli nie, jakie są przewidywania BAS co do wniosków zawartych w sprawozdaniu sekretarza stanu Stanów Zjednoczonych opracowanego na mocy tej ustawy Obecnie obowiązujące ustawodawstwo, praktyka administracyjna i sądowa nie spełniają kryteriów ustawy S.447. Jest to przede wszystkim wynikiem dalszego obowiązywania prawodawstwa nacjonalizacyjnego z lat 1944-1962, m.in. dekretów PKWN z 6 września 1944 r. o przeprowadzeniu reformy rolnej (Dz.U. 1945, nr 3, poz. 13, ze zm.), z 6 września 1946 r. o ustroju rolnym i osadnictwie na obszarze Ziem Odzyskanych i byłego Wolnego Miasta Gdańska (Dz.U. nr 49, poz. 279, ze zm.), z 26 października 1945 r. o własności i użytkowaniu gruntów na obszarze m.st. Warszawy (Dz.U. nr 50, poz. 279), a także ustaw z 3 stycznia 1946 r. o przejęciu na własność Państwa podstawowych gałęzi gospodarki narodowej (Dz.U. nr 3, poz. 17, ze zm.) i z 25 lutego 1958 r. o uregulowaniu stanu prawnego mienia pozostającego pod zarządem państwowym (Dz.U. nr 11, poz. 37, ze zm.; Dz.U. 1968, nr 3, poz. 6), jak również braku ustawy reprywatyzacyjnej ${ }^{4}$.

W konsekwencji możliwe jest odzyskanie własności albo uzyskanie odszkodowania według reguł ogólnych ${ }^{5}$ jedynie w zakresie, w jakim była ona zajęta $\mathrm{z}$ naruszeniem tego prawodawstwa. Zwrot mienia czy zapłata odszkodowania może mieć zatem jedynie charakter częściowy i zależny od konkretnego przypadku. Odbywa się ono obecnie na drodze sądowej (tzw. reprywatyzacja sądowa) ${ }^{6}$. Przy tym Trybunał Konstytucyjny zwrócił uwagę, że nie każdy przejaw nacjonalizacji i przejęcia mienia na podstawie przepisów wydanych w okresie 1944-1962

4 Zob. W.J. Katner, Uwarunkowania prawne reprywatyzacji w Polsce (Zakres przedmiotowy i podmiotowy, roszczenia reprywatyzacyjne), „Państwo i Prawo” 2003, z. 7, s. 17 i n.; J. Szachułowicz, Zasady i organizacja reprywatyzacji, „Państwo i Prawo” 2003, z. 7, s. 28 i n.; K. Zeidler, Reprywatyzacja z perspektywy teoretyczno-prawnej [w:] Krytyka prawa. Niezależne studia nad prawem, t. I, Własność, red. J. Jabłońska-Bonca, Warszawa 2009, s. 229 i n.; K. Osajda, Nacjonalizacja i reprywatyzacja, Warszawa 2009; Ł. Bernatowicz, Reprywatyzacja na przykładzie gruntów warszawskich, Warszawa 2015; Problemy reprywatyzacji, red. A. Jarosz-Nojszewska, P. Legutko-Kobus, Warszawa 2017.

5 W odniesieniu do gruntów warszawskich znaczenie ma ustawa z 21 sierpnia $1997 \mathrm{r}$. o gospodarce nieruchomościami (t.j. Dz.U. 2018, poz. 121). Zob. J. Szachułowicz, Zasady i organizacja, op. cit., s. 30-31. Autor wskazuje, że spora liczba wniosków reprywatyzacyjnych w okresie powstawania tekstu czekała na rozpatrzenie.

6 Zob. Reprywatyzacja $w$ orzecznictwie sądów. Materiały z konferencji naukowej, red. M. Pilich, Warszawa 2016. 
powinien być oceniany negatywnie ${ }^{7}$. Ponadto Trybunał uznał, że obowiązująca Konstytucja nie przewiduje ogólnej normy zobowiązującej ustawodawcę do kompensaty utraty mienia znacjonalizowanego czy przejętego w stosunku do wszystkich byłych właścicieli ${ }^{8}$. Stanowisko to dotyczy także mienia żydowskiego ${ }^{9}$.

W odniesieniu do żydowskiego mienia komunalnego według stanu sprzed wybuchu II wojny światowej sytuacji tej nie zmienia ustawa z 20 lutego $1997 \mathrm{r}$. o stosunku Państwa do gmin wyznaniowych żydowskich w Rzeczypospolitej Polskiej (Dz.U. nr 41, poz. 251, ze zm.). Przewiduje ona bowiem jedynie możliwość zwrotu nieruchomości lub ich części, pod warunkiem jednak, że w dniu 1 września 1939 r. znajdowały się na nich cmentarze lub synagogi, albo w dniu wejścia w życie ustawy znajdowały się budynki komunalne (art. 30 i n. tej ustawy). Nie przewidziano natomiast zwrotu komunalnych nieruchomości niezabudowanych lub zabudowanych innymi niż wymienione w ustawie budynkami.

Współcześnie nie ma możliwości rozwiązania problemu reprywatyzacji mienia żydowskiego generalnie, a o to chodzi twórcom ustawy amerykańskiej. Z całą pewnością obecnie nie wchodzi w grę odzyskanie w naturze lub w wartościach pieniężnych żydowskiego mienia bezdziedzicznego. Można mieć także wątpliwości, czy postępowania prowadzone według obowiązujących przepisów spełniają kryteria ustawy S.447 (zwłaszcza kryterium szybkości).

W tej sytuacji należy się spodziewać, że wnioski zawarte w sprawozdaniu sekretarza stanu przyjętego w wykonaniu ustawy S.447 będą stwierdzały naruszenie kryteriów tej ustawy.

- Drugie zagadnienie dotyczy wpływu projektu ustawy o rekompensacie na ocenę spełniania kryteriów wymienionych w ustawie S.447 dokonaną w odniesieniu do obowiązującego stanu prawnego ${ }^{10}$. W tym kontekście należy zestawić rozwiązania zawarte w tym projekcie z kryteriami ustawy S.447

Ustawa S.447 przewiduje, że prawodawstwo i praktyka covered countries obejmie zwrot mienia wszelkiego rodzaju, tj. z perspektywy podmiotowej mienia osób fizycznych i mienia komunalnego lub religijnego (używa się określenia

7 Zob. orzeczenia TK z 25 lutego 1992 r., sygn. akt K 3/91, oraz z 18 czerwca 1996 r., sygn. akt W 19/95, wydane jednak w okresie przedkonstytucyjnym.

8 Zob. postanowienie TK z 28 października 2015 r., sygn. akt P 6/13, OTK-A ZU 2015, nr 9, poz. 161.

9 Zob. rygorystyczne stanowisko w tej materii: J. Szachułowicz, Status prawny mienia pożydowskiego w Polsce, „Państwo i Prawo” 2004, z. 12, s. 29 i n. Autor był zdecydowanym przeciwnikiem restytucji mienia żydowskiego, gdyż - jego zdaniem - właściciele i ich spadkobiercy przez 20 lat (po 1989 r.) nie podejmowali czynności o przywrócenie im posiadania i nie uwzględniali prawa polskiego, przez co „skutecznie utracili prawo własności”.

10 Należy jednak podkreślić, że projekt ustawy o rekompensacie nie został przygotowany wyłącznie z myślą o zapewnieniu rekompensaty dla Żydów, lecz ma charakter ogólny. 
„rightful owner”, bez różnicowania statusu personalnego właściciela), a z perspektywy przedmiotowej mienia nieruchomego, ruchomego i innych aktywów żydowskich. Z punktu widzenia podmiotowego projekt ustawy o rekompensacie przewiduje, że uprawnionymi do rekompensat są tylko te osoby fizyczne, które na dzień przejścia nieruchomości były obywatelami polskimi, nie utraciły tego obywatelstwa i miały miejsce zamieszkania na terytorium RP, a jednocześnie są obywatelami polskimi w dniu wejścia w życie ustawy (art. 6, z uwzględnieniem specyfiki warszawskiej - art. 9, z zastrzeżeniem art. 11 i 73). Kryteria te poważnie zawężają krąg uprawnionych. Mając na uwadze Żydów, w wyniku ewentualnego zastosowania ustawy, zostaliby oni w istotnym stopniu wyłączeni z zakresu podmiotów uprawnionych, ponieważ duża ich część wyemigrowała w różnych okresach przed, w czasie i po drugiej II wojnie światowej (np. w 1968 r.) oraz przynajmniej w dniu wejścia w życie ustawy nie ma już obywatelstwa polskiego ${ }^{11}$. Projekt ustawy o rekompensacie nie przewiduje zwrotu mienia osobom prawnym (wniosek a contrario $\mathrm{z}$ art. 1).

Prawo do rekompensaty uznaje się w projekcie ustawy za niezbywalne, niepodzielne i dziedziczne (art. 5). Pozwala to zachować prawo do rekompensaty $\mathrm{w}$ razie śmierci uprawnionego przed zakończeniem postępowania. Jednak nie uwzględnia się sytuacji, gdy były właściciel już nie żyje, a żyje tylko jego spadkobierca, najczęściej niemający już obywatelstwa polskiego ${ }^{12}$. Projekt ustawy o rekompensacie ogranicza też to prawo do spadkobierców w linii prostej, co w przypadku Holokaustu może oznacza brak rekompensaty (art. 7 ust. 2 projektu) ${ }^{13}$.

Mając na uwadze kryterium przedmiotowe, należy najpierw zwrócić uwagę, że ustawa S.447 nie różnicuje charakteru mienia mającego podlegać zwrotowi. Istotne jest tylko to, czy jego zajęcia lub transferu dokonano bezprawnie w ro-

11 Trzeba tutaj wskazać, że prawo polskie dopuszcza posiadanie obywatelstwa polskiego i obcego od niedawna (zob. ustawę z 2 kwietnia 2009 r. o obywatelstwie polskim, t.j. Dz.U. 2017, poz. 1462, art. 3). Ustawy o obywatelstwie polskim z 20 stycznia $1920 \mathrm{r}$. (Dz.U. nr 7, poz. 44, art. 1), z 8 stycznia 1951 r. (Dz.U. nr 4, poz. 25; art. 1) oraz z 15 lutego 1962 r. (Dz.U. nr 10, poz. 49; art. 13) przewidywały zasadę wyłączności obywatelstwa polskiego. W rezultacie nabycie obywatelstwa obcego powodowało automatycznie utratę obywatelstwa polskiego.

12 Na stosowanie kryterium posiadania obywatelstwa polskiego jako na kryterium wykluczające z prawa do rekompensaty zwracali uwagę także amb. P. W. Jones w liście m.in. do Z. Ziobry z 13 listopada 2017 r. oraz Światowa Żydowska Organizacja Restytucyjna w liście m.in. do Z. Ziobry z 27 listopada 2017 r. Na marginesie należy zwrócić uwagę na ograniczone oczekiwania wyrażone przez ambasadora Stanów Zjednoczonych, które sprowadzają się do zwrócenia uwagi na potrzebę poszerzenia kręgu podmiotowego uprawnionych. Samo przyjęcie projektu ustawy powitane zostało jednak z zadowoleniem.

13 Zob. na ten temat krytycznie Organizacja Ocalonych i Potomków Holokaustu w liście do min. Z. Ziobry z 27 listopada 2017 r. 
zumieniu tejże ustawy. Tymczasem projekt ustawy o rekompensacie ogranicza prawo do rekompensaty do nieruchomości (na warunkach określonych w art. 3) i zabytków ruchomych (art. 1 ust. 1), a zatem nie wszystkich aktywów (np. udziałów czy akcji w przedsiębiorstwach). Ponadto art. 13 projektu wymienia przypadki, kiedy przejęcie nieruchomości nie powoduje przyznania prawa do rekompensaty. Znajdują się tutaj m.in. przypadki przejścia mienia na podstawie przepisów o majątkach opuszczonych i porzuconych, o nacjonalizacji przemysłu i o reformie rolnej (zob. też art. 12 projektu). Ogranicza to w dużym stopniu zakres prawa do rekompensaty w odniesieniu do żydowskiego mienia nieruchomego (np. nieruchomości rolne, zakłady przemysłowe). Dodatkowo ograniczający skutek ma art. 13 ust. 2, który wyłącza prawo do rekompensaty w odniesieniu do nieruchomości przeznaczonych po dniu przejęcia na cele publiczne i w dniu wejścia w życie ustawy nadal przeznaczonych na te cele.

Ustawa S.447 przewiduje podział mienia na podlegające dziedziczeniu i niepodlegające dziedziczeniu (bezdziedziczne). Jednak w obydwu przypadkach oczekuje się kompensaty. Projekt ustawy o rekompensacie w zasadzie nie reguluje statusu mienia bezdziedzicznego. Natomiast przewiduje się, że gdy nie można ustalić własności nieruchomości, która znajduje się co najmniej od 5 grudnia 1990 r. nieprzerwanie we władaniu Skarbu Państwa lub jednostki samorządu terytorialnego bądź spółdzielni mieszkaniowej albo nie pozostawała w niczyim władaniu, staje się w pierwszym przypadku własnością Skarbu Państwa lub jednostki samorządu terytorialnego albo spółdzielni mieszkaniowej, a w drugim własnością Skarbu Państwa (art. 52-54). Tym samym nie przewiduje się zapewnienia mienia czy kompensaty pieniężnej dla ocalałych z Holokaustu pozostających w potrzebie ani też środków pochodzących z mienia bezdziedzicznego, które byłyby przeznaczone na cele edukacyjne lub inne.

Projekt ustawy o rekompensacie przewiduje, że prawo do rekompensaty za przejęcie nieruchomości przysługuje w dwóch przypadkach: a) gdy została ona przejęta $z$ rażącym naruszeniem prawa albo bez podstawy prawnej; b) gdy została zajęta lub skonfiskowana po dniu 1 września 1939 r. na rzecz władz okupacyjnych albo na rzecz niemieckich lub sowieckich osób prawnych prawa publicznego, na terenach włączonych do ZSRR albo do III Rzeszy Niemieckiej, albo znajdująca się na obszarach okupowanych, o ile jest położona na obecnym obszarze Rzeczypospolitej Polskiej i nie została zwrócona po dniu 19 lipca 1944 r. (art. 12 ust. 1). Ujęcie bezprawności jest tutaj istotnie węższe niż w ustawie S.447 (subsekcja a pkt 3), gdzie nie stosuje się zwłaszcza kryteriów rażącego naruszenia prawa czy też braku podstawy prawnej ${ }^{14}$.

14 Zob. też stanowisko Światowej Żydowskiej Organizacji Restytucyjnej w liście do min. Z. Ziobry z 27 listopada 2017 r. W ten sposób, zdaniem Organizacji, dojdzie do petryfikacji tzw. zgodnego z prawem przejęcia nieruchomości. 
Ustawa S.447 przewiduje też określoną sekwencję w zakresie form odzyskiwania dziedzicznego mienia żydowskiego. Wskazuje, że najpierw powinno dojść do restytucji, a w razie niemożności jej dokonania do zwrotu mienia zastępczego albo wypłaty kompensaty pieniężnej. Projekt ustawy o rekompensacie wyklucza restytucję mienia (rekompensatę w naturze - art. 18). Ponadto w projekcie wprowadza się istotne ograniczenie wysokości rekompensaty - 20\% jej wartości, wyjątkowo w przypadku obligacji skarbowych - 25\%. Tymczasem w ustawie S.447 nie przewiduje się takich ograniczeń. Można nawet przyjąć, że zasadą ma być zwrot aktywów albo ich równoważność w mieniu bądź pieniądzu.

Projekt ustawy o rekompensacie dotyczy także przywrócenia własności niektórych zabytków ruchomych (art. 42 i n.; zob. też ograniczenia wynikające z art. 42 ust. 3). Nie przewiduje się zatem przywrócenia własności innych aktywów ruchomych. Ponadto w projekcie przewiduje się możliwość zachowania posiadania rzeczy przez dotychczasowego władającego, z niewielkimi wyjątkami, przez okres 10 lat oraz prawo wykupu rzeczy przez Skarb Państwa w zamian za $20 \%$ jej wartości (art. 46-48). Ustawa S.447, jak wspomniano, dotyczy wszelkich aktywów i nie przewiduje ograniczeń, o których tutaj mowa.

Ustawa S.447 formułuje także oczekiwanie, że procedury reprywatyzacyjne zostaną tak skonstruowane, iż zapewnią odzyskanie mienia lub uzyskanie słusznej kompensaty w odpowiednio sprawnej procedurze. Procedura przewidziana w projekcie ustawy o rekompensacie jest złożona, co z pewnością wynika ze skomplikowanej materii regulacji. Niemniej wymaga ona przejścia następujących etapów: 1) potwierdzenia prawa do rekompensaty (wojewoda, w drodze decyzji, etap ten obejmuje złożenie wniosku, jego ocenę i wydanie decyzji; art. 19 i n.); b) realizacja prawa do rekompensaty (art. 30 i n.; tak np. spełnienie zadośćuczynienia pieniężnego następuje na wniosek, który podlega adnotacji). O potwierdzenie prawa do rekompensaty należy zwrócić się w terminie 12 miesięcy od dnia wejścia w życie ustawy. Termin nie ulega przywróceniu (art. 12 ust. 2) ${ }^{15}$. Z kolei realizacja prawa do rekompensaty może okazać się na tyle skomplikowana, że zapewnia się ją proporcjonalnie do środków zgromadzonych na ten cel i w miarę możliwości budżetowych na dany rok (art. 31 ust. 1, art. 59 ust. 1 projektu). Może to prowadzić do istotnego opóźnienia w zaspokajaniu roszczeń. W projekcie ustawy o rekompensacie nie przewiduje się procedur chroniących osoby w podeszłym wieku mieszkające poza granicami Polski ${ }^{16}$.

Warto też podnieść, że projektowana ustawa zakłada, że wraz z wejściem w życie ustawy nastąpi umorzenie toczących się postępowań reprywatyzacyjnych (art. 75 ust. 3 i 4), bez względu na etap ich zaawansowania.

15 Taki sam termin przewidziano dla złożenia wniosku o przywrócenie własności rzeczy ruchomej (art. 43 ust. 3).

16 Zob. stanowisko Światowej Żydowskiej Organizacji Restytucyjnej w liście do min. Z. Ziobry z 27 listopada 2017 r. 
Projekt ustawy o rekompensacie, a tym bardziej ustawa, która byłaby uchwalona w następstwie jego wniesienia, z pewnością będzie brana pod uwagę przez sekretarza stanu Stanów Zjednoczonych, ponieważ, czy to jako projekt, czy też jako nowa już ustawa, wprowadza nowe rozwiązania, które nieznane dotąd były prawu polskiemu. Dlatego nie można być zaskoczonym, że wywołają one dodatkowe (w stosunku do stanu prawnego obowiązującego dotąd) uwagi. Część z nich (w zakresie, w jakim wykazano problemy ze spełnieniem kryteriów ustawy S.447) z pewnością będzie krytyczna. U źródeł tej krytyki znajdują się zasadniczo odmienne założenia i podejście ustawodawcy amerykańskiego i projektodawcy polskiego do spraw kompensacyjnych generalnie, w tym w odniesieniu do mienia żydowskiego dotkniętego Holokaustem.

- Trzecia kwestia odnosi się do przewidywanych konsekwencji prawnych,

czyli negatywnej oceny polskich regulacji prawnych i ich wykonywania

w zakresie zwrotu mienia znacjonalizowanego w okresie Holokaustu

Ustawa S.447 jest aktem prawa krajowego i obowiązuje na terytorium Stanów Zjednoczonych i na tym terytorium ma wywierać skutki prawne. Jednak jako taka ma znaczenie dla polityki zagranicznej Stanów Zjednoczonych wobec covered countries. Konkretne jej reperkusje są trudne do przewidzenia. W przypadku obywateli Stanów Zjednoczonych może wejść w grę np. opieka dyplomatyczna, której prawo przysługuje każdemu państwu w stosunku do jego obywateli czy osób prawnych. W jej ramach Stany Zjednoczone mogą dochodzić praw swoich obywateli wobec państw trzecich. Poza tym ustalenia podjęte na mocy ustawy mogą być podstawą działań o charakterze politycznym.

W negatywnym ujęciu skutkiem krytycznej oceny polskiego ustawodawstwa nie może być zaspokojenie się na mieniu RP znajdującym się w Stanach Zjednoczonych, które chroni immunitet sądowy i egzekucyjny. Z uwagi na to, że ewentualne roszczenia są kierowane wobec Polski, a nie jej obywateli, choćby dysponowali mieniem pożydowskim, trudno raczej oczekiwać, że podmiotom dysponującym polską przynależnością państwową mogły być wytaczane procesy przed sądami amerykańskimi.

\section{Podsumowanie}

- Obecnie obowiązujące ustawodawstwo polskie, praktyka administracyjna i sądowa nie spełniają kryteriów ustawy S.447.

- Projekt ustawy o rekompensacie, a tym bardziej ustawa, która byłaby uchwalona $\mathrm{w}$ następstwie jego wniesienia, z pewnością będzie brana pod uwagę przez sekretarza stanu Stanów Zjednoczonych. Ponieważ projekt wprowadza nowe rozwiązania nieznane dotąd prawu polskiemu, to nie można być zaskoczonym, że wywołają one dodatkowe (w stosunku do stanu obowiązującego 
dotąd) uwagi. Część z nich (w zakresie, w jakim wykazano w niniejszej opinii problemy ze spełnieniem kryteriów ustawy S.447) z pewnością będzie krytyczna. U źródeł tej krytyki znajdują się zasadniczo odmienne założenia i podejście ustawodawcy amerykańskiego i projektodawcy polskiego do spraw kompensacyjnych generalnie, w tym w odniesieniu do mienia żydowskiego dotkniętego Holokaustem.

- Ustawa S.447 jest aktem (amerykańskiego) prawa krajowego i obowiązuje na terytorium Stanów Zjednoczonych i na tym terytorium na wywierać skutki prawne. Jednak jako taka ma znaczenie dla polityki zagranicznej Stanów Zjednoczonych wobec covered countries. Konkretne jej reperkusje są trudne do przewidzenia. W negatywnym ujęciu skutkiem krytycznej oceny polskiego ustawodawstwa nie może być zaspokojenie się na mieniu RP znajdującym się w Stanach Zjednoczonych, które chroni immunitet sądowy i egzekucyjny.

\section{Bibliografia}

Bernatowicz Ł., Reprywatyzacja na przykładzie gruntów warszawskich, Warszawa 2015.

Katner W.J., Uwarunkowania prawne reprywatyzacji w Polsce (Zakres przedmiotowy i podmiotowy, roszczenia reprywatyzacyjne), „Państwo i Prawo” 2003, z. 7.

Osajda K., Nacjonalizacja i reprywatyzacja, Warszawa 2009.

Problemy reprywatyzacji, red. A. Jarosz-Nojszewska, P. Legutko-Kobus, Warszawa 2017.

Reprywatyzacja $w$ orzecznictwie sądów. Materiały $z$ konferencji naukowej, red. M. Pilich, Warszawa 2016.

Ryngaert C., Jurisdiction in International Law, Oxford University Press, Oxford 2008, https://doi.org/10.1093/acprof:oso/9780199544714.001.0001.

Szachułowicz J., Status prawny mienia pożydowskiego w Polsce, „Państwo i Prawo” 2004, z. 12.

Szachułowicz J., Zasady i organizacja reprywatyzacji, „Państwo i Prawo” 2003, z. 7.

Zeidler K., Reprywatyzacja z perspektywy teoretyczno-prawnej [w:] Krytyka prawa. Niezależne studia nad prawem, t. I, Własność, red. J. Jabłońska-Bonca, Warszawa 2009. 